\title{
Chapter 17 \\ The Age and Origin of Karez Systems of Silk Road Oases around Turpan, Xinjiang, P.R. of China
}

\author{
Bertil Mächtle, Stefan Hecht, Nicola Manke, Bernd Kromer, \\ Susanne Lindauer, Cheng-Sen Li, Ying Li, Xiaofei Wang and Olaf Bubenzer
}

\begin{abstract}
Age and origin of ancient famous Karez water systems in the oases of the Turpan Basin are open questions in geoarchaeological and historical research. Four hypotheses exist: (a) invention during Han dynasty more than 2000 years ago, (b) transfer of technology from Persian Qanat's more than 3000 years ago, (c) independent invention of local Uyghur people in the 15th century, and (d) late invention during the Chinese Qing dynasty (19th century). Our study dates, for the first time, $8 \mathrm{Karez}$ systems by ${ }^{14} \mathrm{C}$ from plants buried during the formation of Karez mounds, and interviews in order to record oral tradition. We found that the oldest investigated Karez systems originated in the Uyghurian Huihe dynasty (790-1755 AD), which coincides with the oral tradition. A second phase may have occurred during late Huihe/Qing dynasty (after 1755 AD), which may explain why information and the Uygurian term „Kan er jing“ went down in historic Chinese records. In conclusion, hypothesis (d) that oldest Karez systems were built during Qing dynasty has to be rejected because they are at least 600 years old. Instead, during the 3rd Chinese expansion in the 19th century AD the Karez system expanded and got maintenance. A review of regional palaeoclimatic proxies suggests that the origin and the maintenance of the Karez systems took place rather in more humid periods than in more arid ones. However, more research is needed on other Karez systems to test the pending hypotheses of a much older age.
\end{abstract}

Keywords Karez origin $\cdot{ }^{14} \mathrm{C}$ dating $\cdot$ Oral history $\cdot$ Silk roads Climatic fluctuations $\cdot$ Turpan Basin

B. Mächtle $\cdot$ S. Hecht · N. Manke · Y. Li · O. Bubenzer $(\varangle)$

Institute of Geography, Universität Heidelberg-Heidelberg Center for the Environment HCE, Im Neuenheimer Feld 348, 69120 Heidelberg, Germany

e-mail: olaf.bubenzer@uni-heidelberg.de

B. Kromer · S. Lindauer

Curt-Engelhorn-Zentrum für Archäometrie, 68159 Mannheim, Germany

C.-S. Li

Chinese Academy of Sciences, Institute of Botany, Beijing 100093, People's Republic of China

X. Wang

Administration of Cultural Heritage of Turpan, Xinjiang, People's Republic of China

(C) The Author(s) 2019

L. E. Yang et al. (eds.), Socio-Environmental Dynamics along the Historical Silk Road, https://doi.org/10.1007/978-3-030-00728-7_17 


\subsection{Introduction}

The Karez systems of Turpan (Xinjiang province, NW China) are one of the most extensive agglomerations of ancient subterranean tunnel-wells in the world (English 1968), and demonstrate an impressive version of ancient water harvesting technology. In Iran, these systems are known as Qanat (which is an Arabic term, English 1968) or Kariz (which is a Persian term), and in northern Africa as Fuqara. Similar systems are known from Mexico from Spanish times (galerias; Kortum 2004). All in all, such systems are known from more than 34 countries in the world (see Fattahi 2015 and references therein). Many local terms exist in different regions of the world (for a full list, see Salih 2006 and for a discussion of the history see Briant 2001). Located typically in arid environments, with annual rainfall between 100-300 mm (Lightfoot 1997), this sustainable technology gives access to buried water resources by conveying groundwater by gravity to the surface, feeding large oases during the past and documenting the technological potential of our ancestors $\sim 2500-3000 \mathrm{yrs}$. BP, when the first Qanat systems have been invented probably in the surroundings of Tehran or somewhere in Persia (Kobori 1973; Lightfoot 1997). Some ancient capitals were based on Qanat irrigation, e.g. Palmyra (Kobori 1973).

However, the exact dating of the origin of these systems is difficult. Fattahi et al. (2011) dated Miam Qanat in NE Iran by Optical Stimulated Luminescence (OSL), but due to a minimal number of samples the age estimation remains doubtful. If the first dating is correct, the oldest known Karez dates further back to 3600-4300 yrs. BP. Also Bailiff et al. (2015) did OSL on Qanat systems in Aragon, Spain, constructed in the 15 th century.

It is still under debate how and when the technology was transferred further to the Mahgreb in the west and along the Silk Roads to Afghanistan, Kazakhstan (Remini et al. 2014) and to the Turpan oases in the east. The latter is "still a big theme to be resolved" (Kobori 1973). Additionally it remains unclear if there was a single center of innovation or if the systems were developed independently at different places instead (Fattahi 2015).

Chinese scholars assume that the technology was developed independently in mainland China and was brought to Turpan during the first period of Chinese control over the area during the Han dynasty (220 BC-206 AD), which is why Karez rank among the three "Great Ancient Chinese Works". This hypothesis predicates on the description of irrigation in the Turpan oases in Chinese literature. However, in 984 AD the Chinese ambassador Wang Yande travelled to Turpan but he gave no hint to the existence of Karez during this time (Trombert 2008). The author of the Chinese compendium Nongzheng quanshu (农政全书, 1639 AD), Xu Guangqi, a water expert, also did not mention the Karez system, hence why Trombert (2008) assumes that they were absent during this time.

Furthermore, neither the term Karez or the chinese Kan er jing nor a description of specific gravity-fed underground channels can be found before the Qing dynasty. According to a critical study and interpretation of Chinese historical sources, Trombert (2008) dates the Karez of Turpan to the early 19th century. This is close to 
Huntington (1907), who assumed a Persian origin and dated the invention to Turpan to $1780 \mathrm{AD}$. In Chinese history, the Karez are referred to as "The underground great wall" as part of the three great construction projects in ancient China (along with the Great Wall and the Beijing-Hangzhou Grand Canal; Abudu et al. 2011).

Therefore, due to ambiguous historical sources, a precise and representative numeric dating of the Karez systems is needed, in order to identify the period of first construction and the subsequent dynamics of Karez use in the Turpan Basin. Four hypotheses exist (Trombert 2008):

(a) The Karez came to Turpan by technology transfer along the Silk Roads, which enabled exchange at least since the Han dynasty;

(b) The Han brought the technology from mainland China 3000 yrs. ago;

(c) The first Karez have been built during Uyghur reign;

(d) Karez did not exist in the Turpan Basin before Tang dynasty (640-790 AD), most likely they are not older than 200 years.

The aim of the study at hand is to date a set of Karez systems in the Turpan Basin by the use of radiocarbon dating, which is, for distinct times, more accurate than OSL and which was not done before on Qanat/Karez. We use a sampling strategy adapted to the Karez building and maintenance technique, and, by way of comparison, information given by local farmers (oral tradition). Our study is the first step to test some of the hypotheses listed above. After more intense research, questions about the trigger of Karez invention can be asked, e.g. if the systems had strategic functions to support the control points along this part of the Silk Roads or if climatic fluctuations forced the people to harvest additional water.

\subsection{Study Area}

The study area is located in the hyperarid Turpan Depression, with the Aiding saline lake (or Aydingkol, $42^{\circ} 39^{\prime} \mathrm{N} / 89^{\circ} 16^{\prime} \mathrm{E}$ ) in its center (Bubenzer et al. 2016), the third lowest continental point on earth (154 below sea level). The city of Turpan is situated about $20 \mathrm{~km}$ northwest of the lake (Wang and Wu 2003; Fig. 17.1). The Turpan Basin has a complex polycyclic sedimentary history since the Late Permian, in which more than $7000 \mathrm{~m}$ of clastic sediments are accumulated (Shao et al. 1999). Because the northern part of the basin was uplifted in the Late Jurassic, the Bodga Shan as part of the Tianshan Mountains provides the main sediment source since the Early Cretaceous. From the Middle Triassic to the early Tertiary, subsidence took place (Shao et al. 1999). With regard to the Karez systems, the thick fanglomerates of the Piedmont between Bogda Shan and Aiding Lake provide the main aquifers (Fig. 17.2). Due to the complex tectonic picture, surface water and groundwater on its way into the basin follow multiple paths (Halik et al. 2009). The mean annual precipitation in Turpan is $16.6 \mathrm{~mm}$, whereas the Bogda Shan (5455 m a.s.1., Bertrand 2010) receives between 150 and $600 \mathrm{~mm}$ of rainfall (Chen et al. 2013). The Bogda Shan is the "water tower" for the region. There, spring to early summer rainfalls 


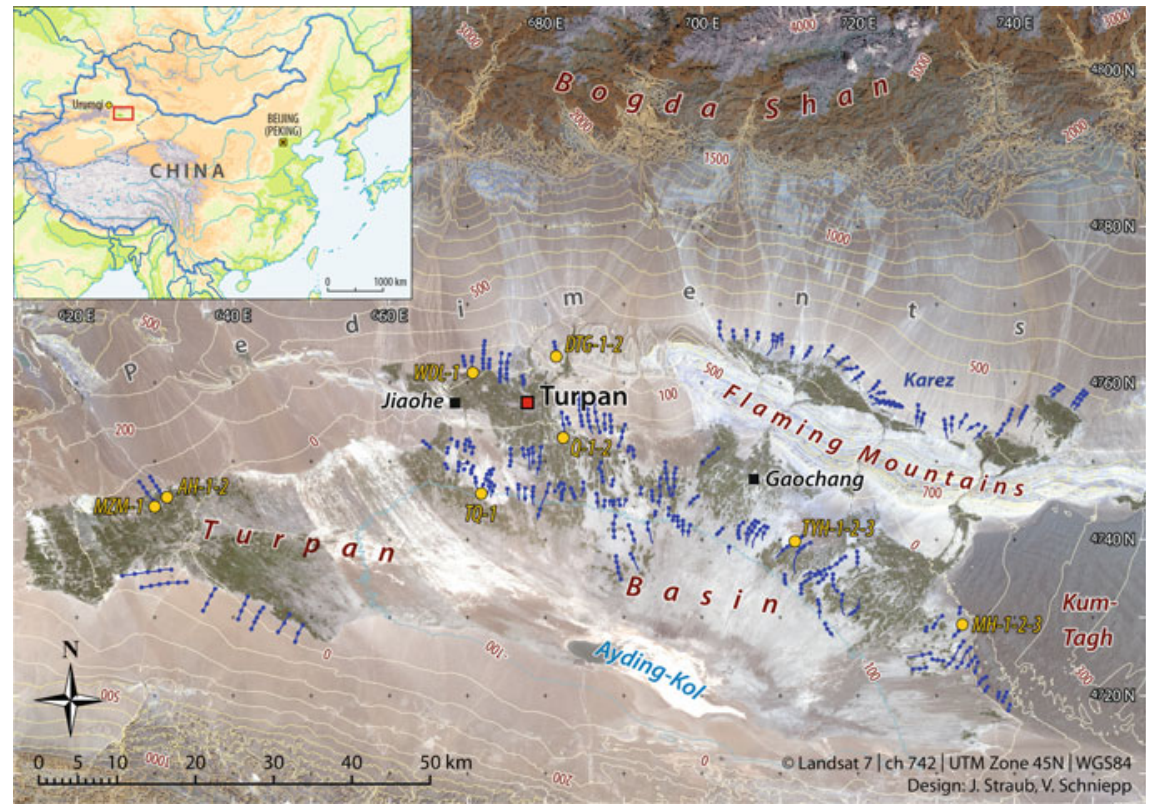

Fig. 17.1 Map of the Turpan oases with Karez distribution (based on Stein 1933). Karez systems which were studied during fieldwork in 2013 are labeled

brought by the westerlies predominate (Domrös et al. 1992; Yang et al. 2004; Fricke et al. 2009). During the summer season, some wet air masses from the polar front can reach the Tianshan from the north and produce, supported by local convective processes, rainfall (Domrös \& Peng 1988). The northern slopes of Bogda Shan receive $80 \mathrm{~mm}$ of winter precipitation (Böhner 2006) due to channeling of northern winds in the Dsungar Basin (Rhodes et al. 1996). The average temperature is $34.1{ }^{\circ} \mathrm{C}$ in July, maximum summer temperatures can reach $50{ }^{\circ} \mathrm{C}$ ( $\mathrm{Li} \&$ Yin 1993), minimum temperatures are around $-16{ }^{\circ} \mathrm{C}$ (Chen et al. 2013), with average winter temperatures of $-8.7{ }^{\circ} \mathrm{C}$ (Ding 2002). High temperatures in summer can last for more than 120 days. The annual average potential evaporation is $2845 \mathrm{~mm}$ (Halik et al. 2009).

The specific environmental setting offers all the features required for successful water harvesting: Firstly, mountains in the hinterland, which are high enough for glaciation and snow accumulation during winter times. Secondly, a piedmont foreland with large alluvial fans and pediments, where the melt water infiltrates into layered fanglomerates of variable permeability (a comparable situation is described by Thomas \& Kidd (2017) in Afghanistan). There, the groundwater table can be reached by digging mother wells as the origin of a Karez system. In the footzone of the Bodga Shan, the aquifers are located between 150-100 m below the surface. Close to the neotectonic chain of the Flaming Mountains, the groundwater table can be found in 20-30 m depth (Lein \& Shen 2006). After passing the Flaming 


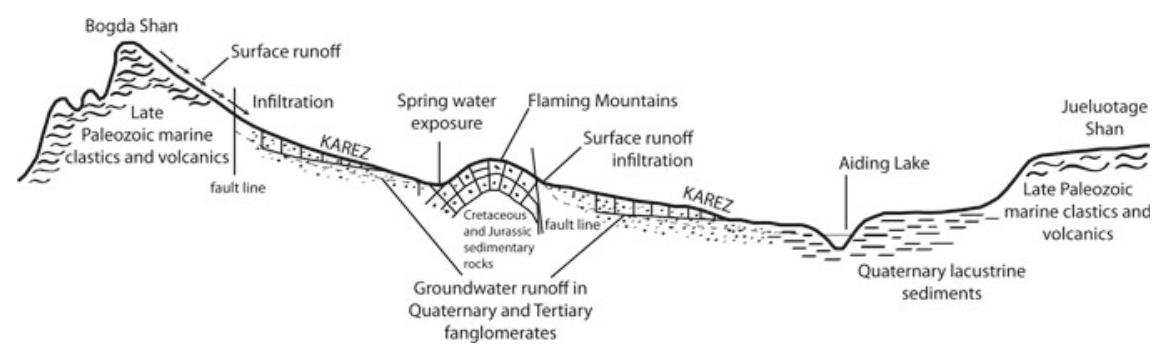

Fig. 17.2 The multiple conversions of surface water and ground water in Turpan Basin (after Lein \& Shen 2006 and Halik et al. 2009 with modifications). The fanglomerates of the Piedmont between Bodga Shan and Aiding Lake act as an aquifer for the Karez systems

Mountains, groundwater feeds also the Karez systems south of the mountain chain (Fig. 17.2).

The surface water from Bogda Shan runs down to the basin until it reaches the barrier of the Flaming Mountains (Kizil tagh). There, only three main gorges give the surface runoff way to the center of Turpan Basin: In the east, Toyuk gorge supports the eastern part with water. In the middle, Shengjinkou gorge feeds the oases of Gaochang, whereas in the west the Turpan gorge with the Davandir River and its bifurcation supported Jiaohe ancient city during the past and recently the city of Turpan. Groundwater flow along faults supports few artesic springs in the basin. To the south, the lower Chöl-tagh ("desert hill") chain do not offer water discharge to the Turpan Basin due to its lower heights and the lack of rainfall and glaciers (Stein 1933). Surface water resources therefore can only support a limited number of people, which is why an expansion of agriculture has been possible only by the building of Karez systems. In the Turpan Basin, the Karez systems are distributed asymmetrically. In the north and east, the irrigated oases are very close to Aiding Lake, whereas to the west there is a larger distance. Stein (1933) ascribed this to a higher salinity to the west, which coincides with the flat topography of the western basin, where large areas become impregnated with salt by evaporation.

\subsubsection{Human Occupation of the Turpan Basin}

The Turpan oasis has been populated for a long time. During the 3rd century BC, the Yuezhe bred horses in the northeastern Turpan Depression in a steppe environment and had a trading relationship with China (Liu 2010). It has to be assumed that for a long time human settlements were supported just by surface and spring water. At least since the 5th century AD, besides agriculture (mainly barley and millet), people practised viticulture (Trombert 2008). With irrigation, two annual harvests are possible (Stein 1933). 
To support the ancient city of Jiaohe ("between the rivers") with water, people dug wells probably before the first century BC. During the reoccupation by the Han in $61 \mathrm{AD}$, numerous wells existed (Bertrand 2010). The majority of wells was dug between the $5^{\text {th }}$ century and the end of Tang dynasty (Li 1999). During the Han and Tang dynasties, trade flourished along the Silk Roads (Liu 2010).

In order to use the Turpan oases as a hub for the Silk Roads, more water was needed. Higher water availability may have been experienced during a more humid past or achieved due to the building of Karez systems. The development of the Turpan oases was controlled by the two capitals: (1) Jiaohe (Fig. 17.1), located on a $30 \mathrm{~m}$ high isolated plateau in the middle of the Davandir River. This city was dependent on tapping groundwater from deep wells (Li 1999). Its decline was probably related to decreasing runoff in the Davandir River and a lowering of the groundwater table. (2) Gaochang, where the situation is somewhat different, as the city is supported on the one hand also by surface water, and on the other hand by Karez systems. Jiaohe and Gaochang existed at least since the beginning of the Han dynasty and lasted until the 15th/16th century. During the independent Gaochang Kindom (500-640 AD), an open air channel system was built around Gaochang (Bertrand 2010 and references therein). If the abandonment of these important cities was triggered by changing runoff of the rivers, palaeoclimatic information is required (see below).

\subsubsection{The Karez Systems of the Turpan Basin}

In contrast to the general description of the Qanat systems that tap water in alluvial deposits (Cressey 1958), there is a greater variety in the Turpan Basin with regard to petrography, topography and hydrogeology (Laureano 2012). The Karez systems have different sources. Firstly, they tap the groundwater flow of large alluvial fans, secondly aquifers on the thick piedmont fanglomerates and thirdly the water from shallow groundwater resources, which are located along faults within the basin close to the Flaming Mountains. The latter sources offer the best water with lowest salinity (Chen et al. 2013).

With regard to their distribution, the Karez systems of Turpan are extraordinary. They had a length of more than $5000 \mathrm{~km}$ in total until the 18th century (English 1968). In the 1950s, 1300 Karez systems with a length of $4000 \mathrm{~km}$ were in use (Sun et al. 2009). Due to the favorable hydrological conditions, the quality of its water is high and meets today's requirements of China sanitary standard for drinking water without treatment (Abudu et al. 2011). Therefore, high quality crops can be produced compared to the use of local groundwater (Cenesta 2003 in Abudu et al. 2011). As the Karez supply year-round water, during winter times the fields are watered to leach out the salts, which were accumulated in the summer season (Abudu et al. 2011).

In recent decades, the sustainable system of gravity-driven utilization of water in the Turpan Basin has been threatened by groundwater drawdown due to the widespread use of less labor-intensive deep-well pumps. Between 1996 and 2006, pumping led to a lowering of the groundwater table in the village of Hope (south of 
Turpan district) from 20 to $33 \mathrm{~m}$ below the surface (Lein \& Shen 2006). As more and more Karez systems run dry, Lein \& Shen (2006) expected a collapse of the last systems between 2015 and 2025. The number of systems declined from 1084 in the year 1949 to 446 in the year 2000 (Turpan District Water Conservancy Bureau 2001, in Lein \& Shen 2006). By 2009, the number had declined to 400 (Sun et al. 2009), which is a fall by $63 \%$ since 1949 , whereas the number of deep wells increased from 500 in 1988 to more than 5000 in 2003 (Abudu et al. 2011). Water discharge out of the Karez systems in the year 2003 was about 170 million $\mathrm{m}^{3}$, enough to support 8800 ha of farmland. However, in 1950 the discharge amounted to 700 million $\mathrm{m}^{3}$, with 24.000 ha of farmland (Sun et al. 2009). Therefore, it is highly recommended to restore and protect the Karez systems, as a sustainable way of water harvesting, in arid lands worldwide because it enlarges the resilience of agricultural systems during years of extreme droughts and lacking surface water.

\subsubsection{Environmental Conditions During the Quaternary}

They have been controlled by climatic fluctuations. Thus, water availability changed markedly during the past. For example, Aiding Lake covered an area of about $3.000 \mathrm{~km}^{2}$ during the last glaciation, and still covered $152 \mathrm{~km}^{2}$ during the rainy season in 1949 (Gao \& Wu 2004; Yu et al. 2001). The colder conditions of the Pleistocene enhanced westerlies and moisture support to this region, whereas during the Holocene, drought increased markedly due to a northward position of the westerlies and higher evaporation, coupled with an enhancement of the Asian summer monsoon system (An et al. 2012). Climatic fluctuations also occurred during the Holocene due to the anti-phase relationship between monsoons and westerlies (Bubenzer et al. 2016). Ran \& Feng (2013) state the Holocene moisture optimum for Xinjiang was from 4-0 ka, due to increasing sea surface temperatures (SST) and evaporation in the North Atlantic region, coupled with intensified westerlies which brought moisture far inland into central Asia. In addition, weaker summer monsoons due to weaker summer insolation decreased the propagation of dry air masses from the south. The Tian Shan is an important climatic divide and separates an arid-steppe climate in the north from an arid-desert climate in the south, including the Turpan Depression. With regard to the late Holocene climate of the Turpan basin detailed information is lacking. Furthermore, it is difficult to extrapolate palaeoclimatic information from abroad geoarchives, as the mountain chains in this region lead to a strong climatic diversity due to synoptic effects (Wolff et al. 2016). The western part of Central Asia from Kabul to Bishkek receives winter rainfall, whereas in the eastern part, e.g. the Tian Shan and the Tarim Basin, summer rainfall prevails (Sorg et al. 2012).

However, in the Tsungar Basin, located north of the Bogda Shan, sediments in Lake Manas indicate two late Holocene lacustrine episodes between 3.5-2.5 and (with a weaker wet pulse) 2.0-1.0 ka cal BP (Rhodes et al. 1996). From the Guliya ice core (western Kunlun Shan), Shi et al. (1999) reconstructed a rapid decrease in temperatures and precipitation at the end of the warm and humid Han dynasty 
250-280 AD, lasting until 970 AD. The medieval warm period between 970-1200 AD was moderate and dry. From 1220 AD onwards, temperatures and precipitation increased until around 1510 AD. During the Little Ice Age (LIA), the variability of climate increased, with strong cold-warm fluctuations. The years 1520-1530 AD were very cold and wet, the 1600s were temperate, although the second half of this century was colder. The 1700s were warmer and wet, the period 1800-1910 AD colder again (Shi et al. 1999). Liu et al. (2010) reconstructed moisture changes during the last millennium by silty-clayey sediments in the hyperarid Tarim Basin and further paleoclimate archives of the region. They concluded that the region was less arid during the LIA from 1490 to $1890 \mathrm{AD}$, in sync with an increase of westerly moisture support to the region, whereas until 1490 and after 1890 AD the region received less moisture. Around 1560 and 1625 AD, two clay layers indicate the peaks of humidity. An increase in humidity is also indicated by an increase in ice accumulation from the Guliya ice core (Yao et al. 1996) between 1550-1830 AD. Until the 5th century, the oases at the southern margin of the Taklamakan, Nixa, Miran and to the east Loulan, located at the margin of the former Lop-Nor, were part of the flourishing kingdom of Kroania (Bertrand 2010). Loulan was abandoned due to shrinking Tarim drainage. At the northern fringe of the Tarim Basin, the oases of Caohu, Tarim, Luntai and Yuli were also abandoned due to drought (Berque 2005). During the 18th century, a massive expansion of Karez systems occurred in the Turpan Basin. Bertrand (2010) suggests this was an adaption to climatic change.

\subsection{Materials and Methods}

For the study at hand, 8 Karez systems along the northern rim of the Turpan Basin were investigated (see Fig. 17.1). They were selected after extensive interviews and the study of archaeological reports, which indicate they constitute the oldest systems still in use.

Karez systems were constructed by digging short vertical shafts into the loose fanglomerates or alluvial fans in the foreland of dryland mountains. In general, these piedmont surfaces are distinctly inclined. At first, the constructors explore for groundwater proximal to the mountains by digging a so-called "mother well". After success, the Karez shafts are dug, beginning at the final (English 1968). Proceeding upslope, further shafts are built and connected by a gently sloped underground channel, draining the water to the outlet in the oasis (see Fig. 17.2) ("telemai", which is an Uyghur term, Lein \& Shen 2006). The length of the Karez in the Turpan basin varies from three to $50 \mathrm{~km}$ (Sun et al. 2009). The distance between the shafts is about 20-30 m close to the outlet and increases to 30-70 $\mathrm{m}$ to the mother well in the oasis. There, some shafts are more than $100 \mathrm{~m}$ deep (Lein \& Shen 2006). It takes up to eight years to build a Karez system (Sun et al. 2008). In comparison, the Qanats in Iran have mean lengths of about $4.2 \mathrm{~km}$ (Kortum 2004), with a maximum of $120 \mathrm{~km}$ (Zarach Qanat, Molle et al. 2004), and vertical shafts of up to $150 \mathrm{~m}$ deep (English 1968). Most likely, the shortest Karez systems, and the shafts close to the basin, are 




Fig. 17.3 Schematic structure of Karez mounds (left), Karez profile MH-3 (right) with buried plants (yellow arrows) close to the old surface (dotted line) and position of plant fragments at the base of a maintenance layer (red arrow). In the background, sparse vegetation is visible despite the hyperarid conditions. Such vegetation existed and was buried also during the time of construction of the Karez systems

also the oldest ones. In Turpan modern Karez had to be dug deeper and the Karez tunnels become longer due to the drawdown of groundwater, which started in the 1950 's, subsequent to the expansion of cultivated land by $30 \%$ during one decade (Lein \& Shen 2006).

During construction, spoil is piled up around the shaft, which builds a protection against sheetflood inflow and eolian input. In Persia, such rings are called "Karvar" (Troll 1963 and references therein). As the fanglomerates consist of deposits from loose clasts to silt and clay, the systems need permanent maintenance. Therefore, the spoil heaps grow successively, forming a "man-made" geoarchive. In order to enable a dating of the Karez systems by the radiocarbon method, we used the fact that the original piedmont surfaces were covered by sparse vegetation. These plants were covered by the spoil heaps during construction (Fig. 17.3). An alternative way of dating the dump is possible by the luminescence method (OSL). However, we rejected this method due to most likely insufficient bleaching of the material during the very short time span of deposition, as is also reported by Fattahi (2015).

Applying radiocarbon dating technology, we got the time of death of the plants and hereby the age of the construction. As Karez mounds grow over centuries by repeated maintenance, the mounds show different layers and some living plants have been incorporated into the mound during maintenance cycles. These layers were also dated. The organic samples were treated with $\mathrm{HCl}$ before burning. Carbon was measured at the MICADAS-AMS device at Klaus-Tschira-Laboratory Mannheim, 
Germany. The ages are given in cal years AD $(1 \sigma)$, calibrated with INTCAL2013 (Reimer et al. 2013) and SwissCal 1.0 (L. Wacker, ETH Zürich) and normalized to $\delta^{13} \mathrm{C}=-25$.

\subsection{Results}

Local people report that some Karez systems have been working since at least the 15 th century AD. Based on such oral information/tradition, 16 test pits were selected, which revealed the typical stratigraphy of spoil heaps (comp. Fattahi 2015; for a detailed description see appendix). A heterogeneous mixture of spoil covers the original, vegetated surface. Grain sizes may vary from coarse gravels to sand and silt. The new surfaces were probably vegetated again. After a maintenance of the system the next sediment layer was deposited. Thus, several periods of spoil heap growth can be distinguished.

Table 17.1 presents the results of radiocarbon dating. Interestingly, three results correlate well, the others less so with information provided by oral tradition. We found that the oldest investigated Karez systems originated in the early 15th century, and that there was a period of maintenance and construction of new systems during the last 300 yrs. More detailed age determination is not possible for the latter period due to the limitations of the radiocarbon method $\left({ }^{14} \mathrm{C}\right.$ plateau) (e.g. Bronk Ramsey 2006).

Numeric datings and oral tradition correlate well for 3 of 10 Karez, 2 of 10 were older and 5 of 10 younger than expected from oral tradition. Tongqi Karez was said having been of service around $1450 \mathrm{AD}$, which was confirmed by our ${ }^{14} \mathrm{C}$ results (1421-1437 AD, $1 \sigma$ ). In addition, construction material found at Dataogou Karez (DTG-1) date to nearly the same age (1410-1426). Mahao 2 Karez was installed at least $1550 \mathrm{AD}$ according to the oral history, but dated older (1416-1435 AD and 1497-1631 AD, respectively). Mierzhamou Karez is older (1532-1643 AD) than oral tradition (1732 AD). Dataogou Karez (1650-1950 AD), Mahao 1 Karez (1700-1954 AD, by oral tradition thought to be 1550 AD), and Ahong Karez (1654-1795 AD, most likely 1751, as oral tradition suggests) date to the expansion period. A Hulu fruit incorporated in the sediments dates a maintenance phase of Mahao 3 Karez to 1678-1951 AD. Tuyuhu Karez dated to 1681-1937 and 1698-1953, respectively, in contrast to oral tradition (1588 AD).

The results show that a number of Karez mounds have to be studied to find the oldest systems. Some Karez mounds may be younger in an old system due to common collapse of older ones and the subsequent construction of a bypass, or the digging of a younger mother well after groundwater drawdown. Therefore, we suggest sampling at least 3 mounds in a Karez system and a careful selection of the sites. 


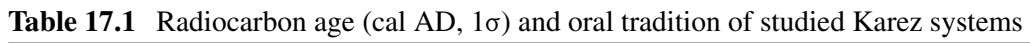

\begin{tabular}{|c|c|c|c|c|}
\hline Karez name & $\begin{array}{l}\text { Sample } \\
\text { description }\end{array}$ & $\begin{array}{l}\text { Age range cal } \\
\text { AD (building } \\
\text { phase) }\end{array}$ & $\begin{array}{l}\text { Age range cal } \\
\text { AD } \\
\text { (maintenance } \\
\text { phase) }\end{array}$ & Oral tradition \\
\hline $\begin{array}{l}\text { Dataogou DTG-1, } \\
\text { maintenance layer }\end{array}$ & plant remnants & & $1694-1952$ & \\
\hline $\begin{array}{l}\text { Dataogou DTG-1, building } \\
\text { rubbish }\end{array}$ & $\begin{array}{l}\text { straw } \\
\text { (construction) }\end{array}$ & $1410-1426$ & & \\
\hline $\begin{array}{l}\text { Datagou DTG-2 from 1st } \\
\text { building phase }\end{array}$ & plant remnants & $1650-1950$ & & \\
\hline Tongqi TQ-1, old surface & plant remnants & $1421-1437$ & & $\begin{array}{l}1450 \text { out of } \\
\text { service }\end{array}$ \\
\hline $\begin{array}{l}\text { Mahao MH-1 above/from } \\
\text { surface }\end{array}$ & plant remnants & $1700-1954$ & & 1550 \\
\hline Mahao MH-2, old surface & plant remnants & $1416-1435$ & & 1550 \\
\hline Mahao MH-3, old surface & plant remnants & $1497-1631$ & & 1550 \\
\hline $\begin{array}{l}\text { Mahao MH-3, maintenance } \\
\text { layer }\end{array}$ & hulu fruit & & $1678-1951$ & \\
\hline $\begin{array}{l}\text { Mierzhamou MZM-1, from } \\
\text { 1st building phase }\end{array}$ & plant remnants & $1524-1643$ & & 1732 \\
\hline $\begin{array}{l}\text { Mierzhamou MZM-1, } \\
\text { maintenance layer }\end{array}$ & wood & & $1651-1950$ & \\
\hline Ahong AH-1, old surface & plant remnants & $1654-1795$ & & 1751 \\
\hline Ahong AH-2, old surface & plant remnants & $1681-1952$ & & \\
\hline Qiong Q-1, old surface & plant remnants & modern & & \\
\hline Qiong Q-2, old surface & plant remnants & $1683-1952$ & & \\
\hline Tuyuhu TYH-1, old surface & plant remnants & $1681-1937$ & & 1588 \\
\hline Tuyuhu TYH-2, old surface & plant needles & $1698-1953$ & $1682-1953$ & 1588 \\
\hline $\begin{array}{l}\text { Tuyuhu TYH-2, } \\
\text { maintenance layer }\end{array}$ & plant remnants & $1682-1952$ & & 1588 \\
\hline Tuyuhu TYH-3, old surface & plant remnants & $1691-1923$ & & 1588 \\
\hline $\begin{array}{l}\text { Wudaolin WDL-1, 1st } \\
\text { building phase }\end{array}$ & plant remnants & $1686-1952$ & & \\
\hline $\begin{array}{l}\text { Wudaolin WDL-1, } \\
\text { maintenance layer }\end{array}$ & plant remnants & $1893-1905$ & & \\
\hline
\end{tabular}




\subsection{Discussion}

Our results show that the oldest investigated Karez systems in the Turpan Basin were constructed during the Uyghur reign and reactivated during the Qing dynasty. At this time, we have no evidence of older Karez systems. During the Tang dynasty (640-790 AD), a large irrigation system, fed by the seasonal runoff of the Xinxing Gorge, was arranged around the city of Gaochang (Fig. 17.1). Some Chinese scholars assign the innovation of Karez from Afghanistan to the period 640-790 AD, the second period of Chinese reign in this region, but Trombert (2008) judges that clearly aboveground channels existed. They were described in detail in several documents, but there is no hint to Karez systems. The Tang period was more humid with increased surface runoff, which might have been sufficient to support the Turpan oases. Similarly, Stein $(1933,238)$ concludes climatic fluctuations prompted the construction of Karez, as “...the economic importance of Turpan was quite as great, if not greater, during ancient and medieval times, when we must assume that its oases depended wholly on irrigation from surface drainage”. Despite the medieval age of the Karez systems, the occurrence of large settlements points to higher water availability at that time (Huntington 1907), most likely from surface runoff or increased spring discharge.

In the 15th/16th century, the abandonment of Jiaohe (Fig. 17.1) and Gaochang, both supported by a certain degree by surface water, may be the result of increased drought. Our study shows that age determinations of Karez systems merely based on historical records, can be misleading. The Qing expansion to the Turpan area started in $1755 \mathrm{AD}$, and the oases have been converted to military agricultural settlements (Trombert 2008). Hening, the Chinese governor, reports one single Karez system, but Qi Yunshi, a Chinese traveler, only reported surface irrigation. Therefore, Trombert (2008) concluded that just a few Karez systems existed during this time.

Overall, due to our oldest radiocarbon datings to the Huihe period, the Karez systems of Turpan have obviously an age of at least 600 years. Therefore, hypothesis d) of Trombert (2008) that still working Karez were built during Qing dynasty for the first time, has to be rejected. Instead, during the 3rd Chinese expansion in the 19th cent. AD, the Karez system expanded and underwent maintenance. The fact that the Chinese transcribed the Uygur word Karez/Kariz to ka'er (Trombert 2008) points to an adaption of both the technique and the terminus.

Although our results so far date the origin of the studied Karez system to Uyghur times, an innovation of systems during the first (Han dynasty, 206 BC-220 AD) or the second (Tang dynasty, 640-790 AD) expansion period is conceivable. From the Taklamakan, early connections to mainland China, India, Pakistan and central Asian steppe regions are known, e.g. from Kunlun Shan and Tian Shan (Debaine-Francfort et al. 2010), which allowed technology transfer along the "Proto Silk Roads".

It is hard to decide if climate triggered Karez activity in the Turpan Basin. Fattahi (2015) hypothesized that people in Iran have been forced to dig channels deeper during more arid periods due to groundwater drawdown, which led to an increase of the spoil heaps. Thus, in addition to the normal maintenance activities, spoil layers shall give the chance to date periods of drought. In contrast, we hypothesize 
that a lowering of the groundwater table would lead to an extension of the Karez gallery further to the mountains, where the groundwater can be reached easily by digging a new mother well. Alternatively, a growth of the spoil heaps may also be triggered by a more humid period, when desiccated Karez could be reactivated (and cleaned) due to a higher groundwater level. In comparison to the regional climate proxies and with regard to our dating results we conclude more humid rather than arid conditions occurred during the construction and maintenance of the investigated Karez systems. At the Kesang Cave, located at the northern margin of the central Tian Shan colder conditions were indicated (see D in Fig. 17.4). The Tarim Basin showed generally wetter conditions (B in Fig. 17.4), which possibly triggered (re)activation of the systems due to increasing groundwater resources. If this holds true, a southerly trajectory of the westerlies and their intensification led to increased moisture transport to the Turpan Basin. As this hypotheses has yet to be tested by further palaeoclimatic information, we suggest the use of independent proxies in order to estimate changes in precipitation and to keep in mind changes in natural resources as a possible trigger of Karez system construction in the Turpan Basin.

\subsection{Conclusions}

The study at hand demonstrates that the presented approach of sampling and dating buried plant remains at the shafts of Karez systems, combined with interviews in order to record indigenous knowledge, is successfully applicable for determining their origin and subsequent maintenance periods. Our results show that the oldest investigated Karez systems in the Turpan Basin were firstly constructed during the Uyghur reign in the early 15 th century and reactivated during the Qing dynasty after around $1750 \mathrm{AD}$. According to the local population, the last new Karez systems, which constitute a sustainable way of water harvesting, were built in the early 1990s. Today, around 400 Karez systems are still in use. However, they are highly endangered due to groundwater lowering after drilling of modern deep wells.

Although the number of Karez systems studied by our Sino-German group is not enough for a clear result, the sampled systems and ages may point to a spatial limitation of early Karez innovation to the eastern part of the basin. There is an open question if the Karez innovation or expansion was due to political and military reasons or due to changes in water availability. From our results and the regional palaeoclimatic context, the periods of innovation and maintenance seem to fit well to short humid periods in eastern Central Asia at the Guliya ice core (Shi et al. 1999) and colder conditions at Kesang cave (Cai et al. 2017). Therefore, climatic factors may have triggered the boom periods along the Silk Roads and supported trade along the pathway crossing the Turpan Basin. We hypothesize that rapid demand of water and food during flourishing times of the Silk Roads trade forced the people to activate additional water resources by constructing Karez systems. 




Fig. 17.4 Karez ages compared to climate proxies. a The Northern Hemisphere temperature record (after Liu et al. 2010, based on Moberg et al. 2005); b Carbon isotope variations of plant leaves/remains preserved in the Tarim Basin in aeolian sediments over time (running average values) and indication of two layers of silty clay deposits in a sequence at the end of the Tarim River, N $39^{\circ} 47^{\prime}$, E $88^{\circ} 23^{\prime}$ (after Liu et al. 2010); c Ice accumulation from Guliya ice core (western Kunlun Shan, Yao et al. 1996); d Oxygen isotope record $\left(\delta^{18} \mathrm{O}\right)$ from the Kesang Cave stalagmite (Tekesi Country, Xinjiang Autonomous Region of China, N 42 ${ }^{\circ} 52^{\prime}$, E $81^{\circ} 45^{\prime}, \sim 2070 \mathrm{~m}$ a.s.l.) (after Cai et al. 2017), higher negative values indicate lower temperatures; $\mathbf{e}$ Carbonate percentage

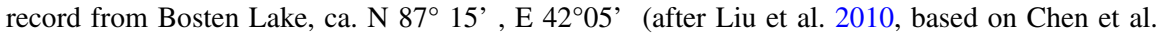
2006), high carbonate contents correlate to lower lake levels and more arid climate. The dating of Karez expansion may coincide with the transition to colder conditions at Kesang Cave (C), which gives hints at probably more humid conditions during these periods 
Assuming the applicability of the same climatic mechanisms, we may postulate that the oases of the Turpan Basin along this section of the Silk Roads received enough surface water during Han and Tang dynasty, which enabled an exchange along the Silk Roads, but also made the activation of additional water resources by Karez systems unnecessary. Finally, we may assume that knowledge about this Persian technique also existed during Han dynasty in the Turpan Basin.

\subsection{Outlook}

The selection of Karez systems, studied by our group, focused on still working systems. Therefore, the question about the oldest Karez systems cannot be answered finally. In order to get a more precise dating of later maintenance periods, which may be a result of cultural dynamics along the Silk Roads and/or hydro-climatic changes, more research is needed. For example, ${ }^{210} \mathrm{~Pb}$-dating is suggested for identifying maintenance period younger than 200 years. Cross-dating with ${ }^{14} \mathrm{C}$ will decrease the possible age range. The next steps of the research will focus on old abandoned systems, identified by remote sensing and geomorphological methods in combination with archaeological work and interviews. Following this approach, we may finally answer the question about the origin of the Karez systems in the Turpan Basin, which are of great importance for the Chinese history, and were set on the tentative list to receive the UNESCO World Heritage status. This will help to protect these traditional and sustainable systems, which also represent great technical and social achievements, for future generations.

Acknowledgements This project was funded by the Administration of Cultural Heritage of Turpan and the Initiative for Excellence, Universität Heidelberg, by the program "Strengthening International Exchange: Mobility in International Research Collaborations". We greatfully thank an anonymous reviewer for helpful comments and for suggestions to assist the paper's English.

\section{Appendix}

Recent description of the studied Karez (cp. XUARBCH 2011): 


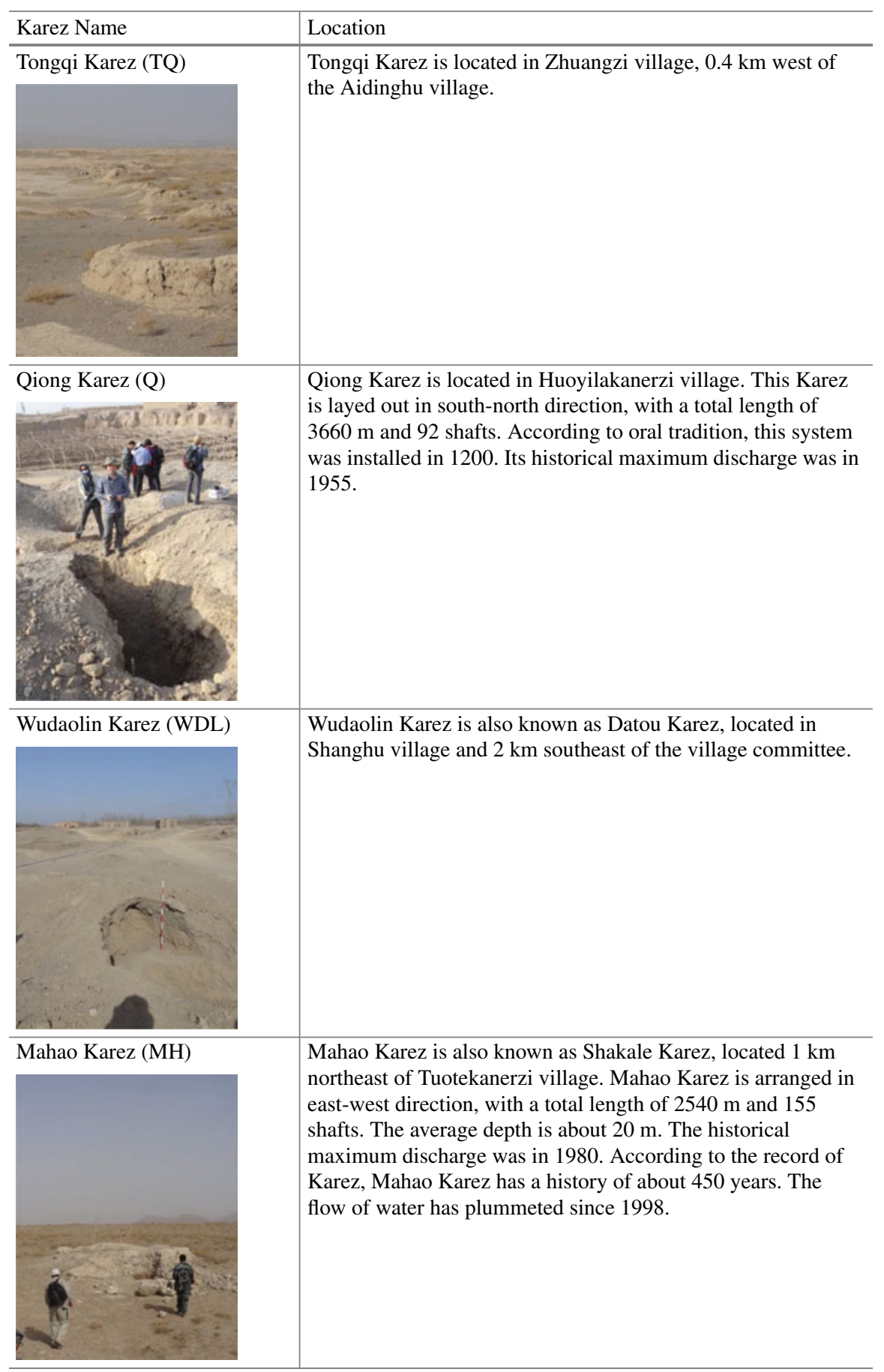


(continued)

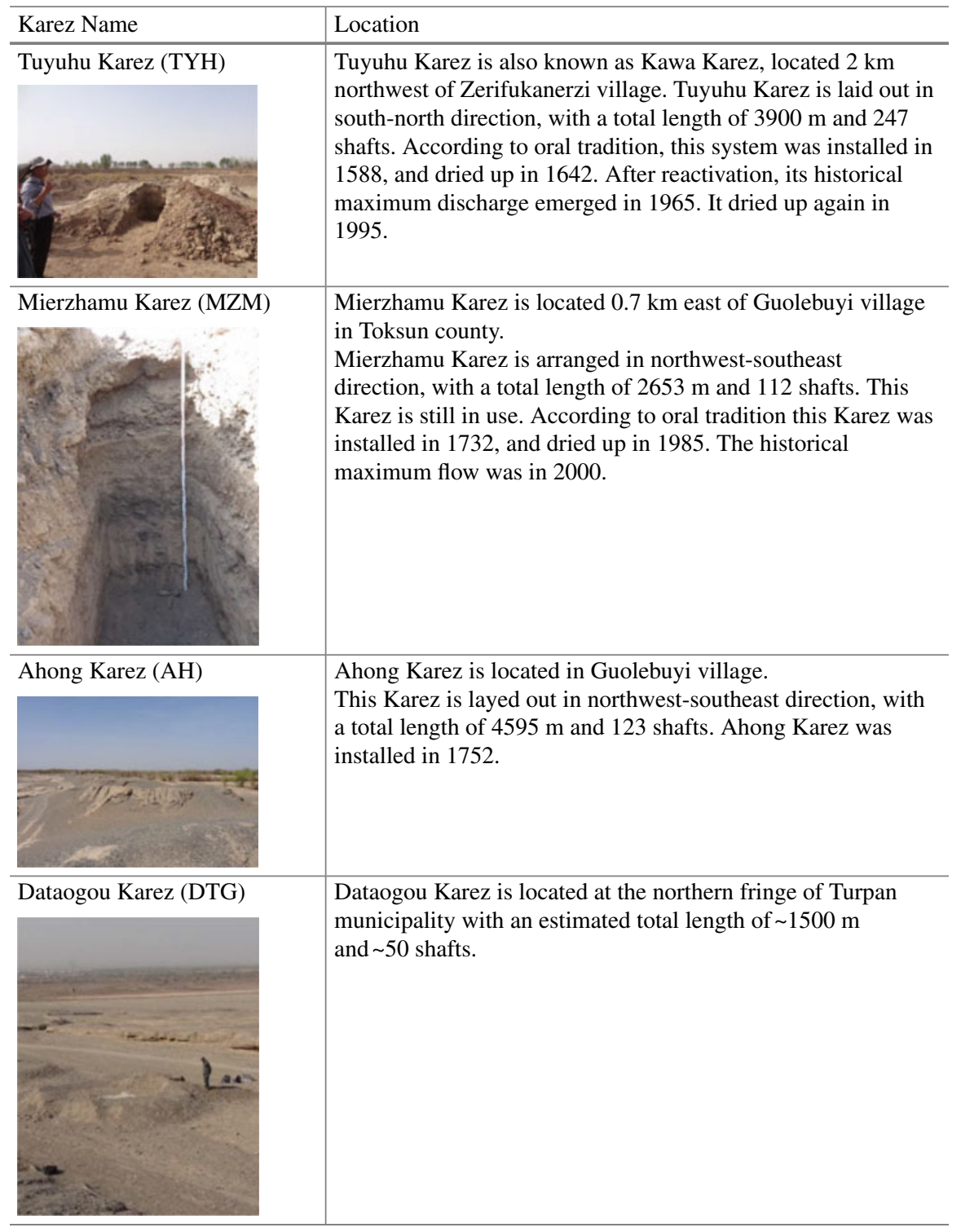




\section{References}

Abudu, S., Cevik, S. Y., Bawazir, S., King, J. P., \& Chunliang, C. (2011). Vitality of ancient karez systems in arid lands: a case study in Turpan region of China. Water History, 3, 225-231.

An, Z., Colman, S. M., Zhou, W., Li, X., Brown, E. T., Jull, A. J. T., et al. (2012). Interplay between the Westerlies and Asian monsoon recorded in Lake Quinghai sediments since $32 \mathrm{ka}$. Scientific Reports, 2, 619. https://doi.org/10.1038/srep00619.

Bailiff, L.K., Gerrard, C.M., Gutierrez, A., Snape-Kennedy, L.M., \& Wilkinson, K.N. (2015). Luminescence dating of irrigation systems: application to a qanat in Aragon, Spain. Quaternary Geochronology, 14(B), 459.

Berque, A. (2005). Sans le Tarim. Espace Géographique 2005/3 (tome 34), 277-280.

Bertrand, A. (2010). The hydraulic systems in Turfan (Xinjiang). The Silk Road, 8, $27-41$.

Böhner, J. (2006). General climatic controls and topoclimatic variations in Central and High Asia. Boreas, 35(2), 279-295.

Briant, P. (Ed.) (2001). Irrigation et drainage dans l'antiquité: qanāts et canalisations souterraines en Iran, en Égypte et en Grèce ; séminaire tenu au Collège de France (Vol. 2, 190 p). Paris: Thotm Éd.

Bronk Ramsey, C. (2006). New approaches to constructing age models: OxCal4. Pages News,14(3), $14-15$.

Bubenzer, O., Hecht, S., Li, C.-S., Li, X., Li, Y., Mächtle, B., et al. (2016). Late Pleistocene (MIS2) environmental changes and palaeoclimatic dynamics around Aiding Lake in the Turpan Basin, Xinjiang province, NW-China. Zeitschrift für Geomorphologie, Suppl., 60(1), 5-27. https://doi. org/10.1127/zfg_supp1/2015/S-00194.

Cai, Y., Chiang, J. C. H., Breitenbach, S. F. M., Tan, L., Cheng, H., Lawrence Edwards, R., et al. (2017). Holocene moisture changes in western China, Central Asia, inferred from stalagmites. Quaternary Science Reviews, 158, 15-28.

Chen, F., Huang, X., Zhang, J., Homes, J.A. \& Chen, J. (2006). Humid Little Ice Age in arid central Asia documented by Bosten Lake, Xinjinag, China. Science in China, Series D. Earth Sciences, 49/12, 1280-1290.

Chen, L., Wang, G.C., Hu, F.S., Wang, Y.J. \& Liu, L. (2013). Groundwater hydrochemistry and isotope geochemistry in the Turpan Basin, northwestern China. Journal of Arid Land. https://doi. org/10.1007/s40333-013-02249-9.

Cressey, G. B. (1958). Qanats, Karez and Foggaras. Geographical Review, 48(1), $27-44$.

Debaine-Francfort, C., Debaine, F., \& Idriss, A. (2010). The Taklamakan Oases: An Environmental Evolution Shown Trough Geoarchaeology. In: Schneier-Madanes, G. \& M.F. Courel (Eds.), Water and sustainability in Arid Regions (pp. 181-202). Springer.

Ding, C. L. (2002). Study of Formation Mechanism of Natural Anhydrous Sodium Sulfate in Lake Aiding. Sea-lake Salt and Chemical Industry, 31(6), 4-7. (in Chinese).

Domrös, M., \& Peng, G. (1988). The climate of China. 360 p.Berlin, Heidelberg:Springer.

Domrös, M., Peng, G., \& Zhang, S. (1992). The Characteristic of the Desert Climate at Turpan, China. Erdkunde, 46, 217-223.

English, P. W. (1968). The origin and spread of Qanats in the Old World. Proceedings of the American Philosophical Society, 12(3), 170-181.

Fattahi, M. (2015). OSL dating of the Miam Qanat (Kariz) system in NE Iran. Journal of Archaelogical Science, 59, 54-63.

Fattahi, M., Aquazadeh, A., Walker, R.T., Talebian, M., loan, R.A., Khatib, M.M. (2011). Investigation on the potential of OSL for dating Qanat in the Dasht-e Bayaz region of north-eastern Iran using the SAR protocol for quartz. Journal of Seismology and Earthquake Engineering, 138 (2), $65-75$.

Fricke, K., Sterr, T., Bubenzer, O., \& Eitel, B. (2009). The oasis as a Megacity: Urumqi's Fast Urbanization in a Semiarid Environment. Die Erde, 140(4), 449-463.

Gao, F. S., \& Wu, X. Y. (2004). The countermeasure analysis of evolution of main environmental factors and sustainable development in Turpan Basin. Turpan Technology, 01, 22-23. 
Halik, A., Jalalidin, A., \& Bian, Z. F. (2009). Discussion on the water resources and their rational development and utilization in Turpan Basin. System Sciences and Comprehensive Studies in Agriculture, 25(3), 355-360. (in Chinese).

Huntington, E. (1907). The depression of Turfan, Central Asia. Geographical Journal, 30(3), 254-273.

Kobori, I. (1973). Some notes on diffusion of Qanat. Orient, 9, 43-66.

Kortum, G. (2004). Die Qanat-Bewässerung auf dem Hochland von Iran und ihre Ausbreitung über die Erde. In U. Hübner \& A. Richter (Eds.), Wasser - Lebensmittel, Kulturgut, politische Waffe: historische und zeitgenössische Probleme und Perspektiven in asiatischen und afrikanischen Gesellschaften (pp. 165-198).

Laureano, P. (2012). Water catchment tunnels: qanat, foggara, falaj. An ecosystem vision. IWA Specialized Conference on Water and Wastewater, Technologies in Ancient Civilizations, Istanbul, Turkey, 22-24 March 2012, 1-13.

Lein, H., \& Shen, Y. (2006). The disappearance of the Karez of Turfan. Acta Geographica Trondheim, Series A, 15, 1-17.

Li, X. (1999). 李肖. “Jiaohe guchengjing diancha baogao” 交河故城井调查报告[The examination of the wells of Jiaohe city]. In Y. Xie (Ed.) 解耀华Jiaohe Gucheng Baohu Yu Yanjiu 交河古城保護與研究[Préservation and Research of the Ancient Ruins of Jiaohe], Urumqi, 1999 (pp. 308-17).

Li, X., \& Yin, J. Y. (1993). The Arid-hot environmental characteristics in Turpan Basin. Arid Land Geography, 16(2), 63-69. (in Chinese).

Lightfoot, D. R. (1997). The origin and diffusion of Qanats in Arabia: New evidence from the northern and southern Peninsula. The Geographical Journal, 166(3), 215-226.

Liu, W., Liu, Z., An, Z., Wang, X., \& Chang, H. (2010). Wet climate during the'Little Ice Age' in the arid Tarim Basin, northwestern China. Holocene, 21(3), 409-416. https://doi.org/10.1177/ 0959683610378881 .

Liu, X. (2010). The silk road in world history. 154 p. Oxford University Press.

Moberg, A., Sonechkin, D. M., Holmgren, K., Datsenko, N. M., \& Karlén, W. (2005). Highly variable Northern Hemisphere temperatures reconstructed from low- and high-resolution proxy data. Nature, 433, 613-617.

Molle, F., Mamanpoush, A., \& Miranzadeh, M. (2004). Robbing Yadullah's water to irrigate Saeid's garden: hydrology and water rights in a village of central Iran. Research Reports: Vol. 80, 43 p. Colombo, Sri Lanka: International Water Management Institute.

Ran, M., \& Feng, Z. (2013). Holocene moisture variations across China and driving mechanisms: A synthesis of climatic records. Quaternary International, 313-314, 179-193. https://doi.org/10. 1016/j.quaint.2013.09.034.

Reimer, P. J., Bard, E., Bayliss, A., Beck, J. W., Blackwell, P. G., Bronk Ramsey, C., et al. (2013). Selection and treatment of data for radiocarbon calibration: An update to the international calibration (INTCAL) criteria. Radiocarbon, 55(4), 1923-1945.

Remini, B., Kechad, R. \& Achour, B. (2014). The collecting of groundwater by the Qanats: A Millenium technique decaying. Larhyss Journal, No. 20, 259-277.

Rhodes, T. E., Gasse, F., Lin, R., Fontes, J. C., Wei, K., Bertrand, P., et al. (1996). A late pleistoceneHolocene lacustrine record from Lake Manas, Zunggar (northern Xinjiang, western China). Palaeogeography, Palaeoclimatology, Palaeoecology, 120(1), 105-121.

Salih, A. (2006). Qanats a unique groundwater management tool in arid regions: the case of Bam Region in Iran. In International symposium on groundwater sustainability (ISGWAS) (pp. 79-87).

Shao, L., Stattegger, K., Li, W., \& Haupt, B. J. (1999). Depositional style and subsidence history of the Turpan Basin (NW China). Sedimentary Geology, 128, 155-169.

Shi, Y., Yao, T., \& Yang, B. (1999). Decadal climatic variations recorded in Guliya ice core and comparison with the historical documentary data from East China during the last 2000 years. Science in China Series D: Earth Sciences, Suppl., 42(1), 91-100. https://doi.org/10.1007/BF02878857.

Stein, A. (1933). Note on a map of the Turfan Basin. The Geographical Journal, 82(3), 236-246. 
Sorg, A., Bolch, T., Stoffel, M., Solomina, O., \& Beniston, M. (2012). Climate change impacts on glaciers and runoff in Tien Shan (central Asia). Nature Climate Change, 2, 725-731.

Sun, Q., Tao, W., Kobori, I., \& Liang, L. (2008). Karez in the Turpan Region of China. In Z. Adeel, B. Schuster, H. Bigas, (Eds.), What makes traditional technologies tick? A review of traditional approaches for water management in drylands (pp. 57-64). UNU Desertification Series No. 8.

Sun, Q., Wang, T., Kobori, I., \& Liang, L. (2009). Karez in the Turpan region of China. In Z. Adeel, B. Schuster, H. Bigas (Eds.), Seeing traditional technologies in a new light - using traditional approaches for water management in drylands (pp. 12-14). The United Nations World Water Development Report 3.

Thomas, D. C., \& Kidd, F. J. (2017). On the margins: enduring pre-modern water management strategies in and around the registan desert, Afghanistan. Journal of Field Archaeology, 42(1), 29-42. https://doi.org/10.1080/00934690.2016.1262188.

Troll, C. (1963). Qanat-Bewässerung in der Alten und Neuen Welt. Mitteilungen der Österreichischen Geographischen Gesellschaft, 105(3), 313-330.

Trombert, É. (2008). The Karez concept in ancient Chinese sources.- Myth or reality? T'oung Pao, 94, 115-150.

Wang, Y. J., \& Wu, S. F. (2003). Environmental change over the Aydingkol Lake region in Turpan Basin. Journal of Glaciology and Geocryology, 25(2), 229-231.

Wolff, C., Plessen, B., Dudashvili, A., Breitenbach, S.F.M., Cheng, H., Edwards, L., \& Strecker, M., 2016. Precipitation evolution of Central Asia during the last 5000 years. Holocene, 1-13. https://doi.org/10.1177/0959683616652711.

XUARBCH (Xinjiang Uygur Autonomous Region Bureau of Cultural Heritage) (2011). The integration of the 3rd national cultural relics census in Xinjiang Uygur Autonomous Region-Xinjiang kan-er-jing (in Chinese). Beijing : Science Press Ltd.

Yang, B., Shi, Y. F., Bräuning, A., \& Wang, J. X. (2004). Evidence for a Warm-humid Climate in Arid Northwestern China During 40-30 ka BP. Quaternary Science Reviews, 23, 2537-2548.

Yao, T. D., Thompson, L. G., Qin, D. H., Tian, L., Jiao, K., \& Yang, Z. (1996). Variations in temperature and precipitation in the past 2000a on the Xizang (Tibet) Plateau: Guliya ice core records. Science in China (Series B), 39(4), 425-433.

Yu, G., Harrison, S. P., \& Xue, B. (2001). Lake Status Records From China: Data Base Documentation. 243 p, MPI-BGC: Jena, Tech Rep 4.

Open Access This chapter is licensed under the terms of the Creative Commons Attribution 4.0 International License (http://creativecommons.org/licenses/by/4.0/), which permits use, sharing, adaptation, distribution and reproduction in any medium or format, as long as you give appropriate credit to the original author(s) and the source, provide a link to the Creative Commons license and indicate if changes were made.

The images or other third party material in this chapter are included in the chapter's Creative Commons license, unless indicated otherwise in a credit line to the material. If material is not included in the chapter's Creative Commons license and your intended use is not permitted by statutory regulation or exceeds the permitted use, you will need to obtain permission directly from the copyright holder.

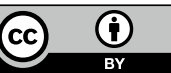

